\title{
The Lithics and Fauna from Heidenschmiede, a Middle Paleolithic Rockshelter in Heidenheim an der Brenz (Swabian Jura)
}

\author{
Susanne C. Münzel' ${ }^{1}$ Berrin Çep² \\ 1 Institute for Archaeological Sciences, Zooarchaeology, University of Tübingen, Germany \\ 2 Department of Early Prehistory and Quaternary Ecology, University of Tübingen, Germany
}

\begin{abstract}
Heidenschmiede is a Middle Paleolithic rockshelter located in Heidenheim an der Brenz. The site was excavated in 1930 by Eduard Peters, but the archaeological remains were never completely analyzed. The lithic and faunal remains have recently been re-analyzed by the authors. The general features of the lithics are indicative of a Middle Paleolithic technology that includes a non-Levallois blade technology. The faunal remains reflect a Mammoth Steppe ecosystem and include mammoth, horse, woolly rhino and reindeer. Carnivore species play a minor role, although some carnivore gnawing is present. The archeological assemblage of this rockshelter demonstrates clear evidence of human activities, such as flint knapping, butchering of game animals, maintaining of hearths (burnt bones) and preparation of organic tools (retouchers).
\end{abstract}

\section{RÉSUMÉ}

Heidenschmiede est un gisement du Paléolithique moyen en abri sous-roche situé à Heidenheim/Brenz. Le site a été fouillé en 1930 par Eduard Peters, mais les restes archéologiques n'ont jamais été complètement analysés. Les restes lithiques et osseux ont été récemment ré-analysés par les auteurs. Les caractéristiques générales de l'outillage lithique indiquent une technologie du Paléolithique moyen qui inclue une technologie laminaire non-Levallois. Les restes de faune reflètent une communauté de type steppe à mammouth et incluent du mammouth, du cheval, du rhinocéros laineux et du renne. Les espèces de carnivores jouent un rôle mineur, bien que des traces de manducation par des carnivores soient présentes. L'ensemble archéologique de cet abri sous-roche contient des preuves claires d'activités anthropiques, telles que la taille du silex, la boucherie sur animaux sauvages, le maintien de foyers (os brûlés) et la confection d'outils en matière dure animale (retouchoirs). 


\section{ZUSAMMENFASSUNG}

Die Heidenschmiede ist ein Felsschutzdach in Heidenheim an der Brenz mit überwiegend mittelpaläolithischen Besiedlungsspuren. Die Fundstelle wurde 1930 durch Eduard Peters ausgegraben, die archäologischen Funde aber niemals vollständig analysiert. Die lithischen und faunistischen Funde wurden kürzlich durch die Autorinnen neu ausgewertet. Die lithische Industrie ist überwiegend mittelpaläolithisch mit einer nicht-Levallois Klingentechnologie. Die Faunenreste spiegeln eine Mammut-Steppen Fauna wider, die durch Mammut, Wildpferd, Wollnashorn und Rentier vertreten ist. Karnivoren spielen eine untergeordnete Rolle, obwohl etwas Karnivorenverbiss nachweisbar ist. Das archäologische Inventar dieses Felsschutzdaches weist deutliche Nachweise menschlicher Aktivitäten auf, wie Steineschlagen, Jagdtierzerlegung, Unterhalten von Feuerstellen (Knochenkohlen) und die Herstellung von organischen Artefakten (Knochenretuscheure).

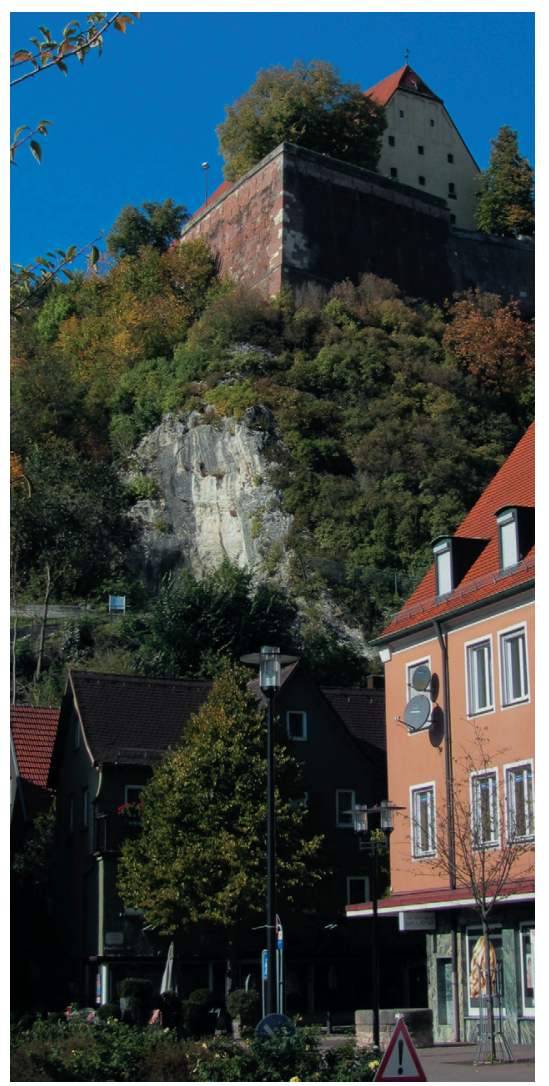

Fig. 1.

The rockshelter of Heidenschmiede today (Photo: Thilo Parg, Wikimedia Commons; License CC BY-SA 3.0).

\section{INTRODUCTION AND RESEARCH HISTORY}

Heidenschmiede is a Middle Paleolithic rockshelter located just below Schloss Hellenstein in the city of Heidenheim. The shelter is situated circa $540 \mathrm{~m}$ asl on the western bank of the Brenz River in the southeastern part of a Jurassic rock formation (Weißjurakalk) (Fig. 1). The site is well known because the first Faustkeil in Baden-Württemberg was found there. It is noteworthy that Heidenschmiede is the only known Middle Paleolithic rockshelter among many cave sites in the Swabian Jura, a point that has implications for the lithic and faunal assemblages.

The site was discovered in 1930 by the local amateur researcher Hermann Mohn, who, with the help of local residents, conducted the first excavation at the rockshelter (Fig. 2). Mohn recognized a stratigraphic order of the finds, but did not continue excavating according to layers after realizing that the stratigraphy was disturbed by a medieval stone wall. He allegedly left a block of unexcavated sediment, between 90 and $130 \mathrm{~cm}$ in thickness. But when Eduard Peters from the Landesdenkmalamt Baden-Württemberg completed the excavation in the same year, undisturbed sediments were rare, and hardly any finds were uncovered. Moreover, Mohn's profile drawings were no longer preserved. In addition, no strata courses were recognizable in the profile block as a result of disturbances caused by wall construction (Peters 1931).

Lacking information regarding their stratigraphic provenance, Peters sorted the lithic artifacts in chronological order according to typological criteria. He thus suggested the existence of "Acheulian, Mousterian and Mesolithic" levels at the site (Peters 1931). 
Later, in the 1950s and 1960s, Hansjürgen Müller-Beck (1956) and Gerhard Bosinski (1967) re-classified the lithic assemblage from Heidenschmiede. Müller-Beck argued that several Middle Paleolithic occupation events were represented at the site. According to Bosinski, several assemblage groups are present but only the "Micoquian" could be clearly identified.

Fritz Berckhemer from the Natural History Museum in Stuttgart was the first to study the faunal remains, with Florian Heller studying the microfauna and Kálmán Lambrecht the avifauna (Peters 1931). Peters reports a total bone weight of $5 \mathrm{~kg}$. The species list included mammoth, rhinoceros, horse $(\mathrm{MNI}=3$, counted by the teeth), reindeer $(\mathrm{MNI}=6$, counted by the antler pieces), wolf, fox, hare $(\mathrm{MNI}=2)$, marmot $(\mathrm{MNI}=2)$, lemmings and several birds. The researchers did not report any remains of larger carnivores.

\section{RESEARCH QUESTIONS}

The faunal and lithic assemblages from Heidenschmiede are of interest for several reasons. First, Heidenschmiede is the only rockshelter with evidence for Middle Paleolithic occupation in the Swabian Jura, where cave sites predominate. Up until now, the Heidenschmiede lithic material was well known for its various bifacial tools, but these are not the most important component of the assemblage. Far more interesting are the non-bifacial pieces executed using the raw material found at the site. In his publication, Peters onlymentioned lithics that he defined as modified tools (Peters 1931). It is now our opinion that some of these were misidentified.

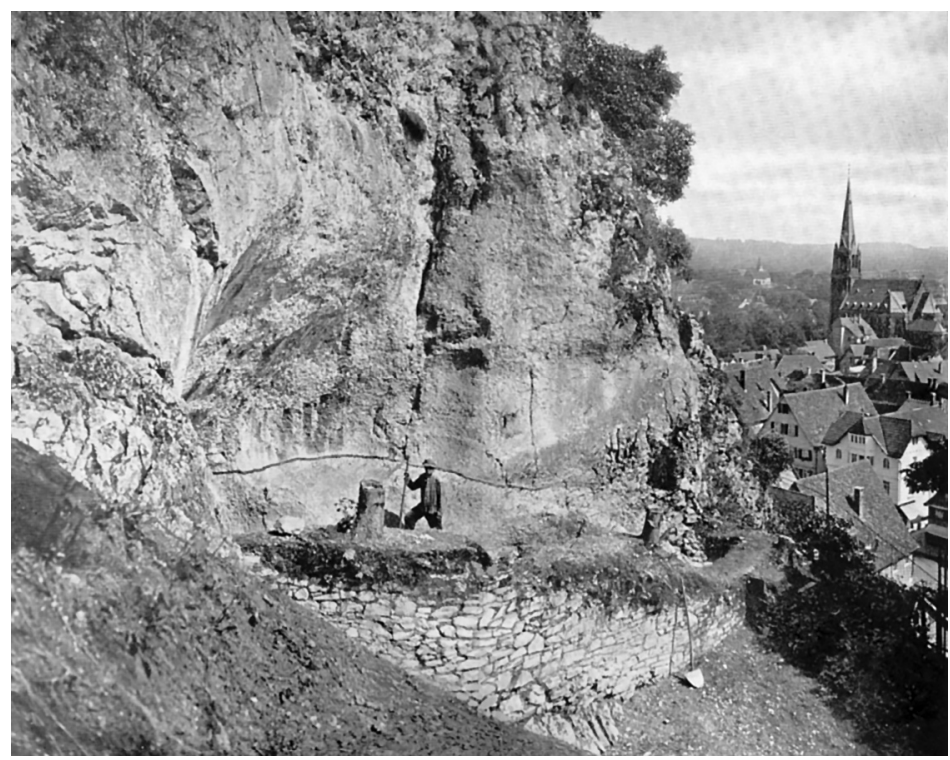

Fig. 2.

Heidenschmiede during the 1930 excavation (Peters 1931, Plate I). 
Because of the lack of stratigraphy, the origin of the embedded finds, and thus the number of different assemblages or cultural horizons, are unknown. We present below a detailed description of the finds from Heidenschmiede.

Furthermore, we have carried out technological and typological analyses on the stone artifacts in order to test the existence of chronologically different assemblage units and their possible relation to the faunal remains. The work here is a contribution to current knowledge regarding the variety of Middle Paleolithic assemblages in the Swabian Jura.

Since the analysis of the stone artifacts is still in progress, the results presented here are preliminary in nature. We are aware of the stratigraphical problems associated with the site and note that our results should be regarded with a degree of caution.

\section{MATERIAL}

The Heidenschmiede archaeological assemblage is stored in three different locations: the Landesmuseum Württemberg in Stuttgart (LMW), the Natural History Museum in Stuttgart (SMNS) and the Museum Schloss Hellenstein in Heidenheim.

\section{Lithic assemblage}

According to Peters (1931), the lithic assemblage included 5000 pieces. The current re-examination includes 1461 pieces from a total number of slightly more than 2200 available artifacts. Thus, we assume that Peters was providing more of an estimate of the number of finds. The majority of the lithics are stored in the Museum Schloss Hellenstein in Heidenheim. Most of the modified pieces, which were formerly thought to be of importance, are housed in the LMW. A few pieces are stored with the faunal remains in the SMNS.

The analysis of the lithic industry is based on a system of attribute analysis, including metric and morphological characteristics as well as technological features and raw material determination.

\section{Faunal material}

Peters (1931) estimated that the total weight of the faunal remains was $5 \mathrm{~kg}$. Our recent analysis has shown it to be almost three times as much, namely $14 \mathrm{~kg}$ of bones. There are also other obvious discrepancies. He reports $0.7 \mathrm{~kg}$ of charred bones, while we found $3.22 \mathrm{~kg}$. It is unclear why the quantity of lithics was so overestimated and the fauna so underestimated in the report from Peters (1931).

The overall state of preservation of the fauna is not very good and seems to depend on the storage conditions of the bones. The better preserved bones are housed in the SMNS $(n=274)$ and in the LMW $(n=5)$. Presumably, after his excavation in 1930, Peters gave the best pieces to the 
museums in Stuttgart (SMNS and LMW). In his report, Peters depicted five specimens (Peters 1931, Plate IV, 1-5): two bone retouchers, a marmot mandible, a small shed reindeer antler and a mammoth upper molar. The molar, however, could not be found in the LMW when we studied the material. The fauna from the storage facility in Heidenheim $(n=2776)$ was less well preserved. The majority of the bones are moderately bleached, calcareous and show fresh breaks from handling in storage. Exceptions are the reindeer bones, which were generally better preserved than bones from other species in the SMNS and in Heidenheim. This could have chronological implications. Consequently, we decided to obtain radiocarbon dates and selected three bones with anthropogenic modifications, which were processed at the Laboratory of Ion Beam Physics, ETH in Zurich. The samples included a poorly preserved horse metatarsal with an impact mark (HDS-1), one well-preserved but broken retoucher from a Bos/Bison metacarpal (HDS-2), and one well-preserved reindeer femur shaft bearing scraping marks and an impact mark (HDS-4, Table 1, Fig. 3). All three dates place the Heidenschmiede inventory in the Middle Paleolithic time range, meaning we can probably rule out attributions of the fauna and lithics to the Upper Paleolithic.

\begin{tabular}{|l|l|l|l|l|l|l|l|l|}
\hline Inventory Nr. Sample Nr. Sample & Description & $\begin{array}{l}\text { Anthropogenic } \\
\text { modification }\end{array}$ & 14C age BP $^{ \pm 1 \sigma}$ & 2 sigma range cal BP & Lower \\
\hline HDS 366 & ETH-86100 & HDS-1 & $\begin{array}{l}\text { Horse, } \\
\text { metatarsal }\end{array}$ & impact mark & 40882 & 612 & 45525 & 43315 \\
\hline HDS 438 & ETH-86101 & HDS-2 & $\begin{array}{l}\text { Bos/Bison, } \\
\text { metacarpal }\end{array}$ & retoucher & 46325 & 1178 & $>47512^{*}$ \\
\hline HDS 204 & ETH-86102 & HDS-4 & $\begin{array}{l}\text { Reindeer, } \\
\text { femur }\end{array}$ & $\begin{array}{l}\text { impact \& } \\
\text { striations }\end{array}$ & 48732 & 1583 & $>49965^{* *}$ \\
\hline
\end{tabular}

\section{Table 1.}

${ }^{14} \mathrm{C}$ dates of 3 bones with anthropogenic modifications from Heidenschmiede. Calendar age $2 \sigma$ range cal BP-calibrated ranges 95.4\% confidence Level, 0xCal v4.3.2 Bronk Ramsey (2017), IntCal13 atmospheric curve (Reimer et al 2013).

*Date may extend out of range $-46325 \pm 1178 \mathrm{BP}$.

**Date probably out of range $-48732 \pm 1583 \mathrm{BP}$.

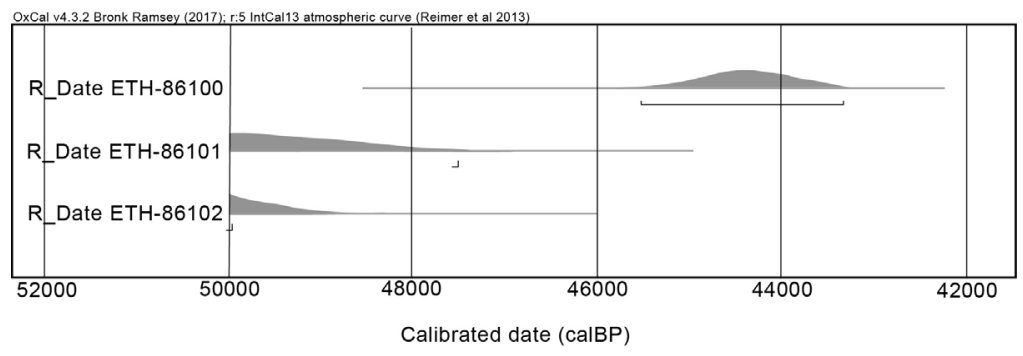

Fig. 3.

Calibrated ${ }^{14} \mathrm{C}$ dates of Heidenschmiede. 


\section{RESULTS FOR THE LITHICS}

\section{Previous classification of the assemblage}

Eduard Peters (1931) identified tools, retouched flakes and blanks and a few cores, but found no nodules in the assemblage. He classified several bifacial tools, together with Mousterian points (so-called Handspitzen), points of various shapes and scrapers as belonging to the Acheulian. $\mathrm{He}$ assigned the majority of the finds, about 4000 pieces, including Mousterian points (Handspitzen), points, scrapers, endscrapers, knives and burins, to the Mousterian. Peters did not recognize any evidence of the Levallois concept. He considered microlithic artifacts to be Late Mesolithic in origin. Peters identified $90 \%$ of the raw material used for the stone artifacts as local Süßwasserkieselkalk from the Steinheim Basin. He also identified Jurassic chert from the Steinheim Basin, local Jurassic chert and a few pieces made of quartz.

Peters interpreted Heidenschmiede as a knapping site and suggested that the base camps were located on the plateau above the rockshelter, on the site where Hellenstein Castle stands today. The small number of faunal remains found on the site seemed to support this interpretation.

Müller-Beck (1956: 24) and Bosinski (1967: 50) re-classified the lithic assemblage. They suggested that it was composed of a small number of bifacial tool types, points, varying types of scrapers, notched and denticulated pieces, a handful of cores and retouched blades and flakes. According to Bosinski (1967), flakes with a distinctive "all-over beaded retouch" ("umlaufend perlretuschiert") are characteristic of Heidenschmiede (“Abschläge Typ Heidenschmiede”) (Bosinski 1967: 50).

Results of the re-examination

\section{Raw Material used}

At Heidenschmiede only locally available raw materials, from just below the site (a maximum distance of $5 \mathrm{~km}$ ), were used (Fig. 4). Local Jurassic siliceous limestone (formerly termed tertiärer Süßwasserkieselkalk) was the main raw material used and represents $70 \%$ of the pieces. Fine-grained Jurassic chert from primary deposits is the next most common raw material (about 10\%); today it is found on tilled land and in forests, as well as in the river gravels of the Brenz River (Beuer 1971; Burkert 1999; Çep et al. 2011; Herkert et al. 2015). The remaining artifacts were made of gravels of radiolarite, "lydit," quarzite, Keuperhornstein and Muschelkalkhornstein, which were probably collected from the nearby Brenz River. In addition, we identified a few pieces as tertiary chert from the Steinheim Basin. 


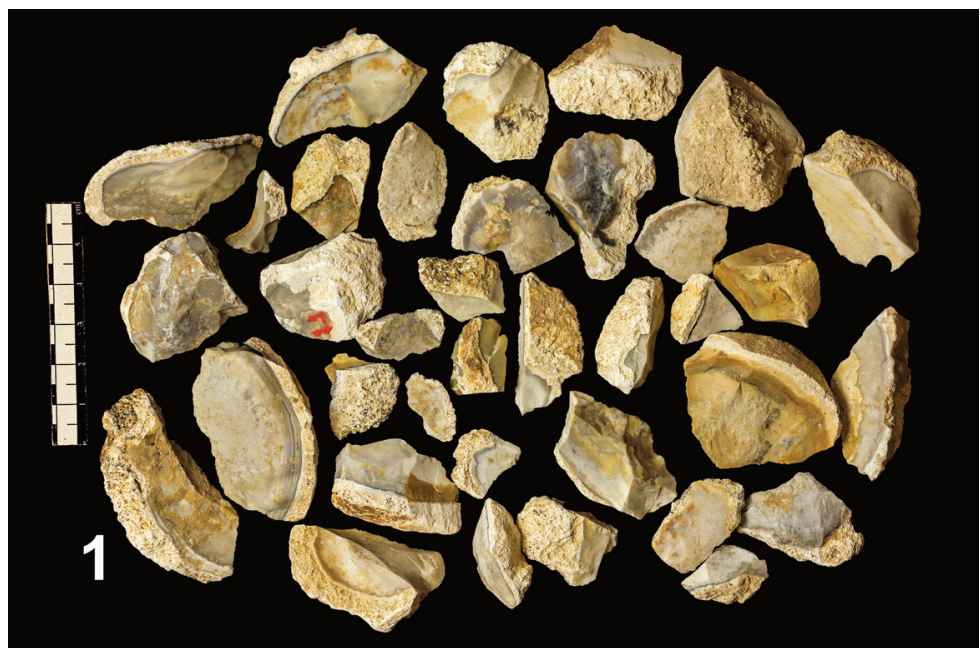

Fig. 4.

Raw material:

1) local fine-grained Jurassic chert; 2) river gravels; 3 ) local Jurassic siliceous limestone (Photos: Yvonne Berardi).
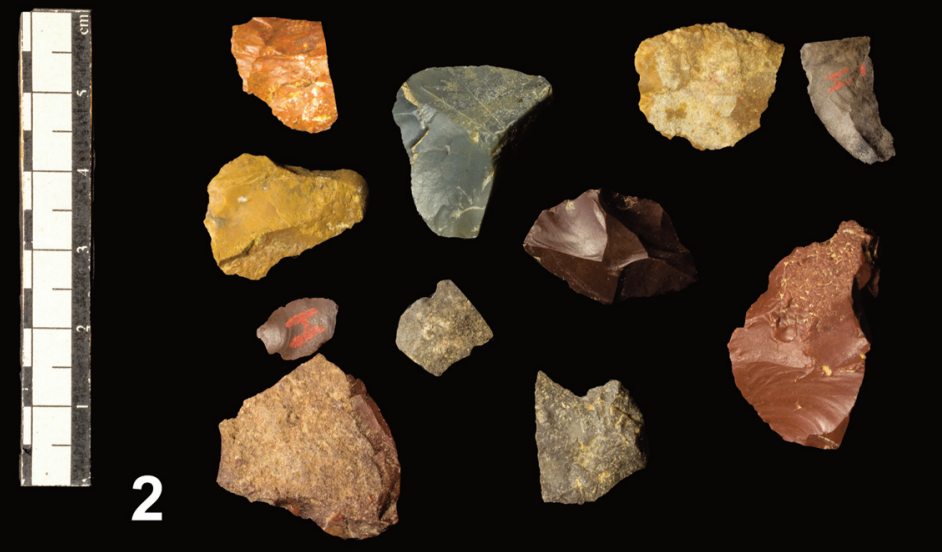

3

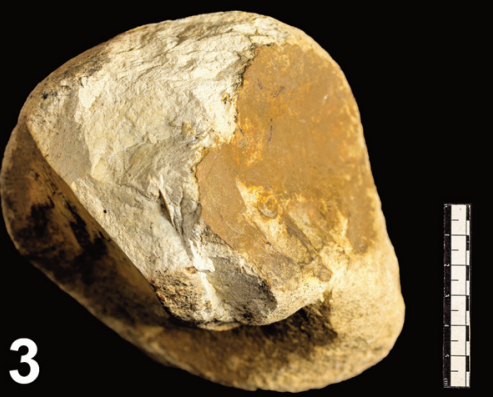


Münzel, Çep

Table 2.

Frequency of formal artifacts.

\begin{tabular}{|c|c|}
\hline Retouched tools & Total \\
\hline bec & 5 \\
\hline bifacial retouched flake & 1 \\
\hline bifacial retouched scraper & 1 \\
\hline bifacial retouched undefined piece & 3 \\
\hline borer & 4 \\
\hline transverse scraper, straight & 1 \\
\hline transverse scraper, convex & 3 \\
\hline multiple burin & 1 \\
\hline double scraper, straight & 1 \\
\hline single scraper, straight with endscraper cap & 1 \\
\hline single scraper, convex & 12 \\
\hline single scraper, straight & 3 \\
\hline truncated and laterally retouched piece & 1 \\
\hline notched/denticulated piece & 2 \\
\hline Groszaki & 4 \\
\hline truncated and lateral retouched blade & 1 \\
\hline Keilmesser & 3 \\
\hline Keilmesser "Typ Klausennische" & 1 \\
\hline endscraper & 3 \\
\hline naturally backed knive & 6 \\
\hline Micoquekeil & 1 \\
\hline biface & 1 \\
\hline single retouched blade & 15 \\
\hline double retouched blade & 1 \\
\hline retouched Levallois point & 1 \\
\hline retouched pseudo-Levallois point & 1 \\
\hline retouched flake & 35 \\
\hline retouched frost debris & 1 \\
\hline point & 7 \\
\hline convergent scraper & 2 \\
\hline burin & 2 \\
\hline undefined tool & 1 \\
\hline unifacial retouched piece & 1 \\
\hline unifacial retouched scraper, convex & 1 \\
\hline déjeté scraper, straight/concave & 1 \\
\hline Total & 129 \\
\hline
\end{tabular}




\section{Composition of the assemblage}

Relative to the total number of available pieces that have been examined until now ( $\mathrm{n}=1461)$, formal tools are poorly represented (8.8\%) (Table 2). The same applies for cores, which are represented by only 16 pieces (1.0\%). The tools display a markedly Middle Paleolithic composition, consisting of various scraper types, bifacial and unifacial retouched tools, naturally backed knives and some bifaces, whereas bifacial tools are not as important as earlier researchers had determined. Of particular note are the so-called Groszakis (Fig. 5), which Bosinski (1967: 50) considered "umlaufend perlretuschierte Abschläge Typ Heidenschmiede" ("all-over beaded, retouched flakes of the type Heidenschmiede"). These types of tools are known primarily from the Eastern European Middle Paleolithic (Kozlowski and Kozlowski 1996), but they also occur in the Middle Paleolithic of Sesselfelsgrotte in the nearby Franconian Jura (Freund 1968: 150; Richter 1997: 184) and in northwest Germany (Hillgruber 2007; Tafelmeier 2011: 161). Heidenschmiede provides the first known example of Groszakis in the Swabian Jura.

\section{The raw materials of the formal tools}

Although siliceous Jurassic limestone is the most common raw material found on the site, the proportion of tools made of other raw materials is relatively high (Tables 3-5).

Siliceous limestone was most frequently used for retouched flakes and blades, various scrapers and for nearly all becs. The only bifacial tools in

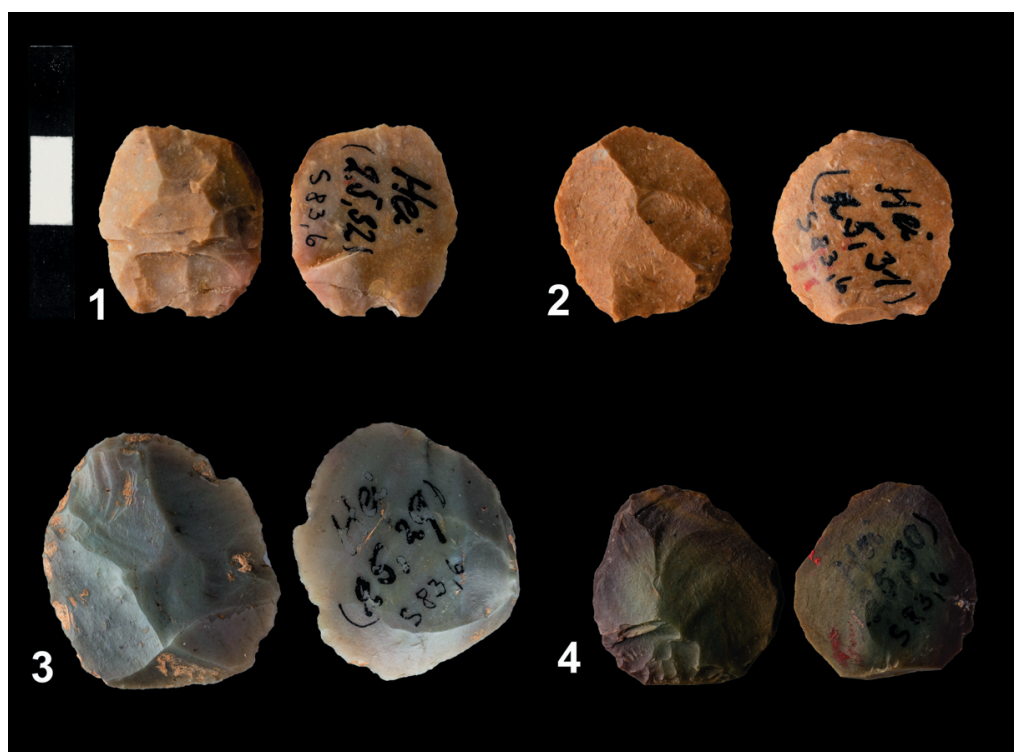

Fig. 5.

1-4) Groszakis

(Photos: Yvonne Berardi). 
this material include one biface, one bifacial point, one Keilmesser and the Micoquekeil (Fig. 6), which was mentioned by Bosinski (1967) as evidence for the Micoquian at the site. All in all, the artifacts made of siliceous limestone are mainly Middle Paleolithic in character, with the exception of two endscrapers, which possibly come from Upper Paleolithic contexts.

Table 3.

Tools made on local Jurassic siliceous limestone.

Fig. 6.

1) bifacial point;

2) Keilmesser, 3) biface

(Photos: Yvonne Berardi).

\begin{tabular}{|l|c|}
\hline Tools & Number \\
\hline bec & 4 \\
\hline single scraper. convex & 8 \\
\hline single scraper. straight & 2 \\
\hline truncated and laterally retouched piece & 2 \\
\hline notched/denticulated piece & 2 \\
\hline endscraper & 1 \\
\hline naturally backed knive & 1 \\
\hline Micoquekeil & 1 \\
\hline biface & 12 \\
\hline retouched blade & 1 \\
\hline retouched Levallois point & 24 \\
\hline retouched flake & 1 \\
\hline retouched frost debris & 3 \\
\hline point & 1 \\
\hline convergent scraper & 1 \\
\hline undefined tool & 1 \\
\hline déjeté scraper, straight/concave & 66 \\
\hline Total & 1 \\
\hline
\end{tabular}

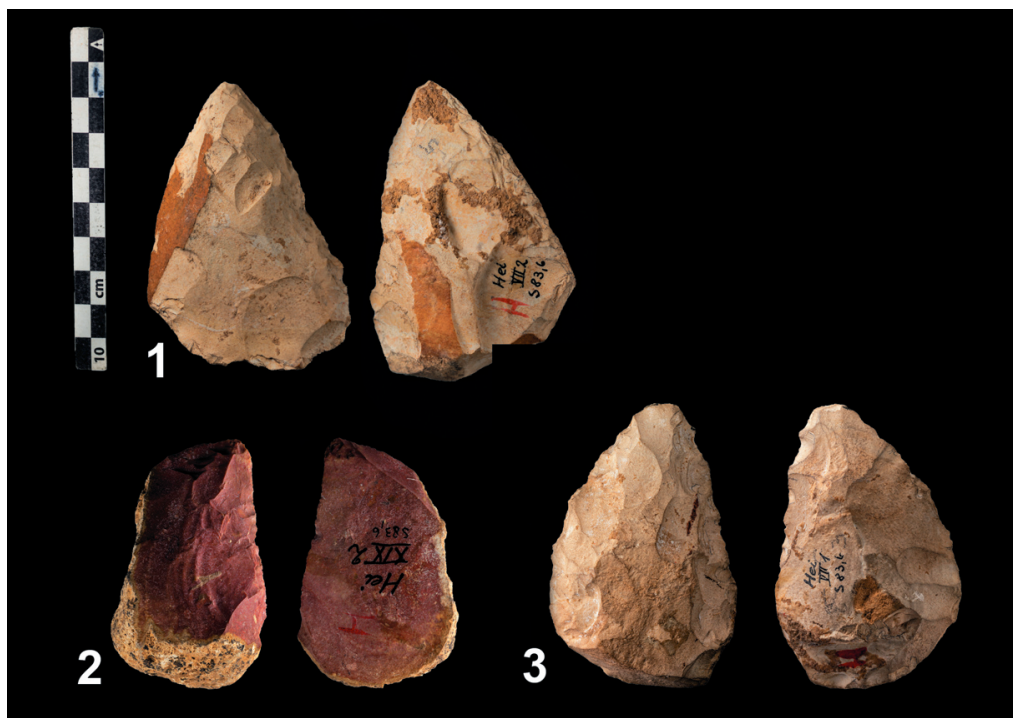


The Lithics and Fauna from Heidenschmiede, a Middle Paleolithic Rockshelter

\begin{tabular}{|c|c|c|c|c|c|}
\hline Tools & Radiolarite & Lydite & $\begin{array}{l}\text { Muschel- } \\
\text { kalk chert }\end{array}$ & $\begin{array}{c}\text { Tertiary. Jurassic } \\
\text { chert }\end{array}$ & Total \\
\hline bifacial retouched piece & 2 & & & & 2 \\
\hline Groszaki & 1 & & & & 1 \\
\hline Keilmesser & 1 & & & & 1 \\
\hline naturally backed knife & 1 & & 2 & & 3 \\
\hline transversal scraper, straight & & 1 & & & 1 \\
\hline transversal scraper, convex & & & & 1 & 1 \\
\hline retouched flake & & 1 & & 1 & 2 \\
\hline Total & 5 & 2 & 2 & 2 & 11 \\
\hline
\end{tabular}

Table 4.

Tools of other non-Jurassic raw materials.

\begin{tabular}{|l|c|}
\hline Tools & Total \\
\hline bec & 1 \\
\hline bifacial retouched flake & 1 \\
\hline bifacial retouched scraper, conkave & 1 \\
\hline bifacial retouched, indet. piece & 1 \\
\hline borer & 4 \\
\hline transversal scraper, convex & 2 \\
\hline double scraper, straight & 1 \\
\hline single scraper, straight & 1 \\
\hline single scraper, straight with endscraper cap & 1 \\
\hline simple scraper, convex & 4 \\
\hline Groszaki & 3 \\
\hline truncated and laterally retouched blade & 1 \\
\hline Keilmesser & 2 \\
\hline endscraper & 1 \\
\hline naturally backed knife & 4 \\
\hline single retouched blade & 2 \\
\hline double retouched blade & 1 \\
\hline single retouched flake & 1 \\
\hline point & 1 \\
\hline convergent scraper & 1 \\
\hline burin & 1 \\
\hline multiple burin & 1 \\
\hline unifacial retouched piece & 1 \\
\hline unifacial retouched scraper, konvex & 1 \\
\hline Total & 1 \\
\hline
\end{tabular}

Table 5.

Tools of fine-grained Jurassic chert. 
Amongst artifacts made from fine-grained Jurassic chert and the raw materials from the river gravels, scrapers are the dominant tool type. The four Groszakis were also produced from these raw materials (Fig. 5), and it is notable that most of the unifacial and bifacial retouched tools, as well as the naturally backed knives, were produced with this raw material variant (Fig. 7). There are two small backed pieces, which could be termed Keilmesser in a broader sense (Fig. 7: 1,2). There are a few tool types, such as single and multiple burins, truncated blades and endscrapers, that display Upper Paleolithic attributes.

Fig. 7.

1-2) small Keilmesser-like tools; 3) point; 4) retouched flake; 5) bifacial tool; 6) naturally backed knife; 7) convergent scraper (Photos: Yvonne Berardi).

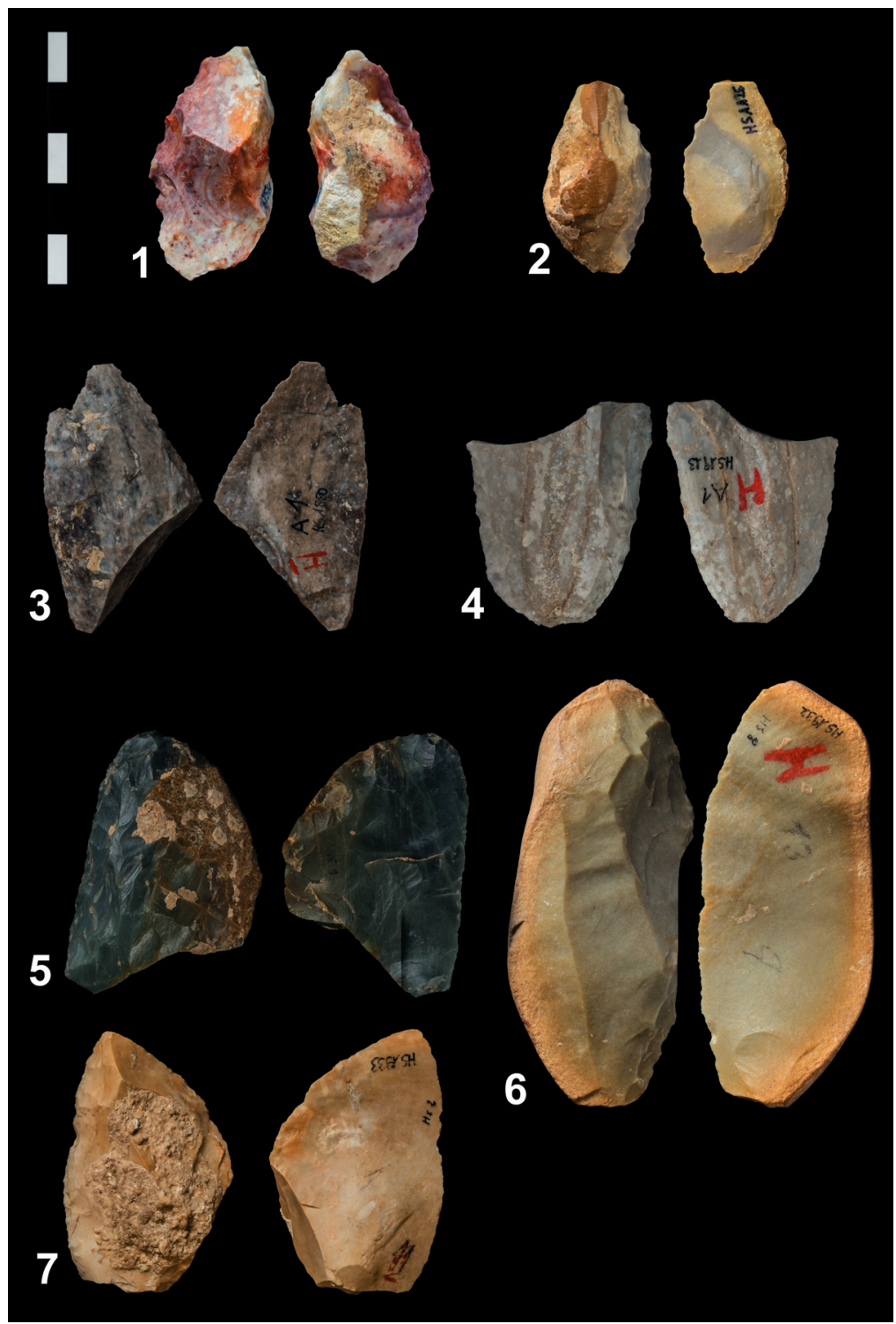

The Rhine During the Middle Paleolithic: Boundary or Corridor? 
Most of the 16 cores show evidence of Levallois features, or are reduced to such an extent that the core is no longer determinable. A single discoid core and a La Quina type core are also present. Among the cores, only Jurassic chert was used, with raw materials from secondary deposits (river gravels) not represented.

One reduction strategy should be emphasized here. It is present in a core as well as in the preferential blanks available at the site (Fig. 8). The conical core with two debitage axes, which are perpendicular to each other, shows unipolar circumferential blade scars on its longitudinal axis. Its vertical surface is concentrically reduced by using the blade scars as striking platforms. The resulting blanks are éclat débordants and sometimes Pseudo-Levallois points and flakes, which are produced when preparing a Levallois core (Boëda 1994: 230). Both blades and this type of flake are common in the Heidenschmiede assemblage, which suggests that targeted production was intended. Judging from the size classes, it can be assumed that the entire chaine opératoire, at least of this reduction strategy, occurred at the site (Fig. 9).
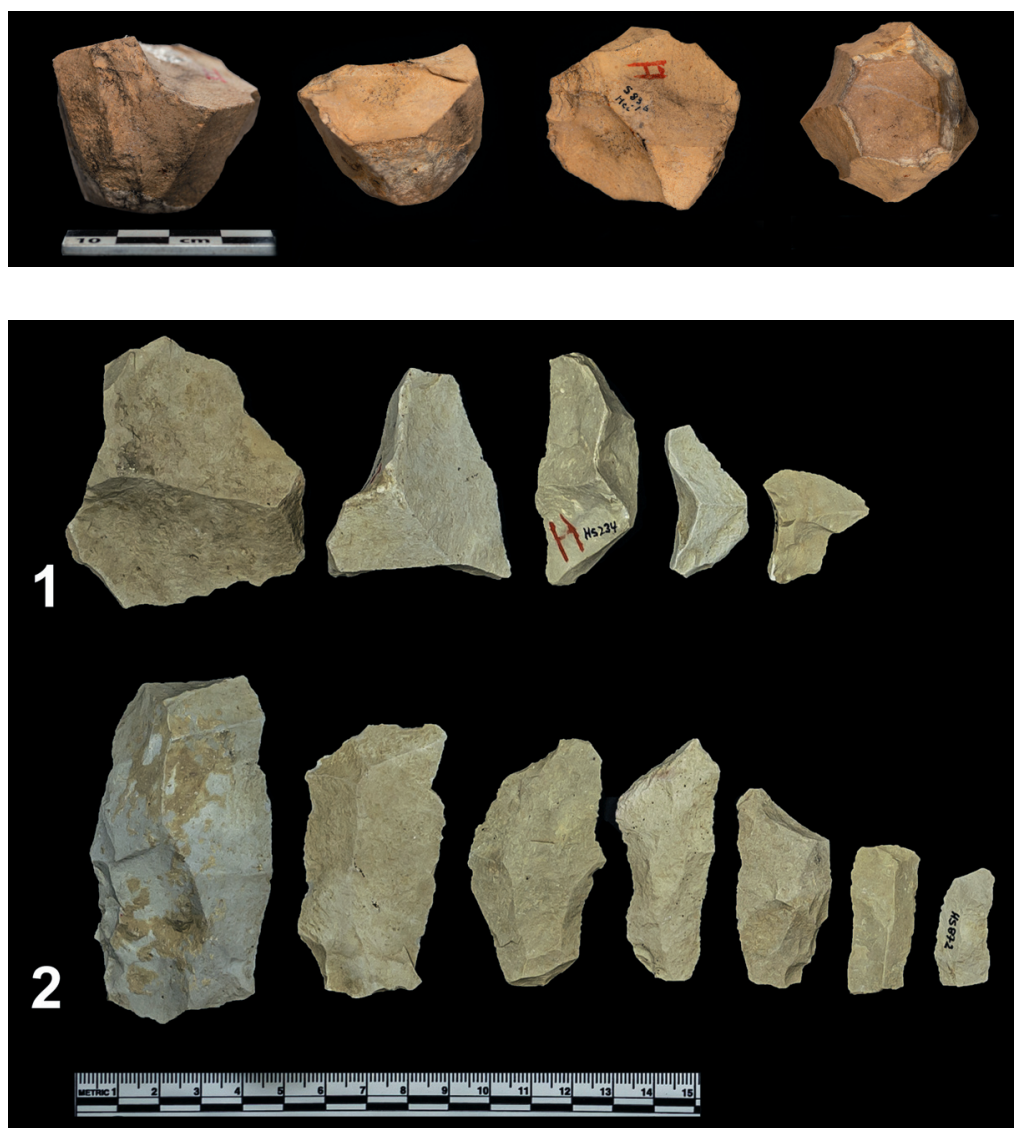

Fig. 8.

Pyramidal frustum-shaped core (Photos: Yvonne Berardi)

Fig. 9.

1) blanks resulting from horizontal reduction (éclat débordant and pseudoLevallois points); 2) blades resulting from vertical reduction (Photos: Yvonne Berardi). 


\section{LITHIC CONCLUSIONS}

The results of the lithic analysis differ in some respects from those presented in previous research, though we were also able to confirm some aspects of the earlier work. The assemblage is mainly Middle Paleolithic in character, with Upper Paleolithic and Mesolithic finds not identified to date. Heidenschmiede shows a wide range of Middle Paleolithic tools. This is probably due to the fact that the site had been visited repeatedly over a long period of time during the Middle Paleolithic of the Swabian Jura, dating probably from the last interglacial (Conard and Fischer 2000: 10) to 45-40,000 BP (Richter et al. 2000; Conard 2009; Higham et al. 2012). Although the chronological classification based on typological criteria is problematic, there are some diagnostic features that may provide possible clues. Groszaki, Keilmesser and Micoquekeile are usually associated with the Micoquien of western Central Europe as defined by Bosinski (1967), and for which the term Keilmessergruppen is used today. The G-layers of the Sesselfelsgrotte in the Franconian Jura, which included Groszaki, belong to the late Keilmessergruppen, i.e., after the Last Glacial Maximum within oxygen isotope stage 3 (Weißmüller 1995; Richter 1997, 2002). This provides at least some indication as to the time period for Heidenschmiede.

Due to the great variability of these technological concepts and their changing occurrence over time and space, these features are not suitable for a chronological classification of the finds from Heidenschmiede. It is, however, remarkable that a non-Levellois blade technology can be proven for the first time for the Swabian Jura. Radiocarbon dates confirm the Middle Paleolithic origin of the blade production.

The inhabitants of Heidenschmiede completely processed the local Jurassic chert. Raw materials from secondary deposits, which they used less often, were brought on site as modified tools. A similar behavior is also documented at the cave sites in the Swabian Jura.

\section{FAUNAL RESULTS}

\section{Taphonomic considerations}

The taphonomic situation in a rockshelter is, in some respects, comparable to an open-air site. Compared to cave sites, open-air and rockshelter sites were used less intensively by non-human predators; it is therefore more likely that humans brought the faunal remains on site. Another similarity with open-air sites is the often poor preservation of organic remains compared to cave sites.

Weathering, the most common natural modification ( $n=59$ or $1.9 \%$ ), is primarily observed on unidentifiable specimens. This is followed by carnivore gnawing ( $\mathrm{n}=23$ or $0.8 \%)$, acid-etching $(\mathrm{n}=19$ or $0.6 \%)$ and root 
etching $(n=4)$. Destruction of the faunal material by carnivore gnawing is not very common. As mentioned above, the primary problem for preservation in this assemblage has been its inadequate handling at the storage facilities.

\section{Human subsistence}

The faunal analysis for Heidenschmiede is based on 3044 bone fragments with a total bone weight of almost $14 \mathrm{~kg}$. Due to poor preservation and a relatively high proportion of burnt bones in the assemblage, $81 \%$ of all bone specimens (Table 6) and just over $45 \%$ of the total bone weight (Table 6 and Fig. 10) were only identifiable to size class.
Table 6.

Heidenschmiede, species list with number and bone weight (in grams).

\begin{tabular}{|c|c|c|c|c|}
\hline Taxon & NISP & NISP \% & weight & weight $\%$ \\
\hline Hare (Lepus sp.) & 29 & 1.0 & 35.7 & 0.3 \\
\hline Marmot (M. marmota) & 5 & 0.2 & 13.0 & 0.1 \\
\hline indet. Microfauna & 52 & 1.7 & 4.5 & 0.0 \\
\hline Wolf (Canis lupus) & 5 & 0.2 & 157.3 & 1.1 \\
\hline indet. middle-large carnivores & 11 & 0.4 & 27.6 & 0.2 \\
\hline Red/Arctic fox (Vulpes/Alopex) & 6 & 0.2 & 6.0 & 0.0 \\
\hline Bear (Ursus sp.) & 9 & 0.3 & 189.6 & 1.4 \\
\hline Lion (Panthera leo spelaea) & 1 & 0.0 & 1.7 & 0.0 \\
\hline Mammoth (M. primigenius) & 3 & 0.1 & 1167.8 & 8.5 \\
\hline Wild horse (Equus ferus) & 79 & 2.6 & 2336.1 & 16.9 \\
\hline Woolly rhino (Coelodonta antiquus) & 24 & 0.8 & 1515.1 & 11.0 \\
\hline Wild boar/Domestic pig (Sus sp.) & 1 & 0.0 & 1.7 & 0.0 \\
\hline indet. Cervidae & 22 & 0.7 & 134.6 & 1.0 \\
\hline Red deer (Cervus elaphus) & 2 & 0.1 & 26.0 & 0.2 \\
\hline Reindeer (Rangifer tarandus) & 153 & 5.0 & 1127.4 & 8.2 \\
\hline Wild cattle (Bos/Bison) & 5 & 0.2 & 123.4 & 0.9 \\
\hline Chamois (Rupicapra rupicapra) & 2 & 0.1 & 20.1 & 0.1 \\
\hline indet. small ruminants & 116 & 3.8 & 477.6 & 3.5 \\
\hline indet. large ruminants & 15 & 0.5 & 225.0 & 1.6 \\
\hline indet. no size class & 208 & 6.8 & 66.0 & 0.5 \\
\hline indet. hare/fox size and smaller & 73 & 2.4 & 9.4 & 0.1 \\
\hline indet. small ruminant/carnivore size & 6 & 0.2 & 8.0 & 0.1 \\
\hline indet. ibex/deer size & 293 & 9.6 & 612.4 & 4.4 \\
\hline indet. bear/horse size & 1856 & 61.0 & 4453.2 & 32.2 \\
\hline indet. mammoth/rhino size & 36 & 1.2 & 1059.5 & 7.7 \\
\hline Birds (Aves) & 32 & 1.1 & 20.0 & 0.1 \\
\hline Total & 3044 & 100.0 & 13818.7 & 100.0 \\
\hline
\end{tabular}




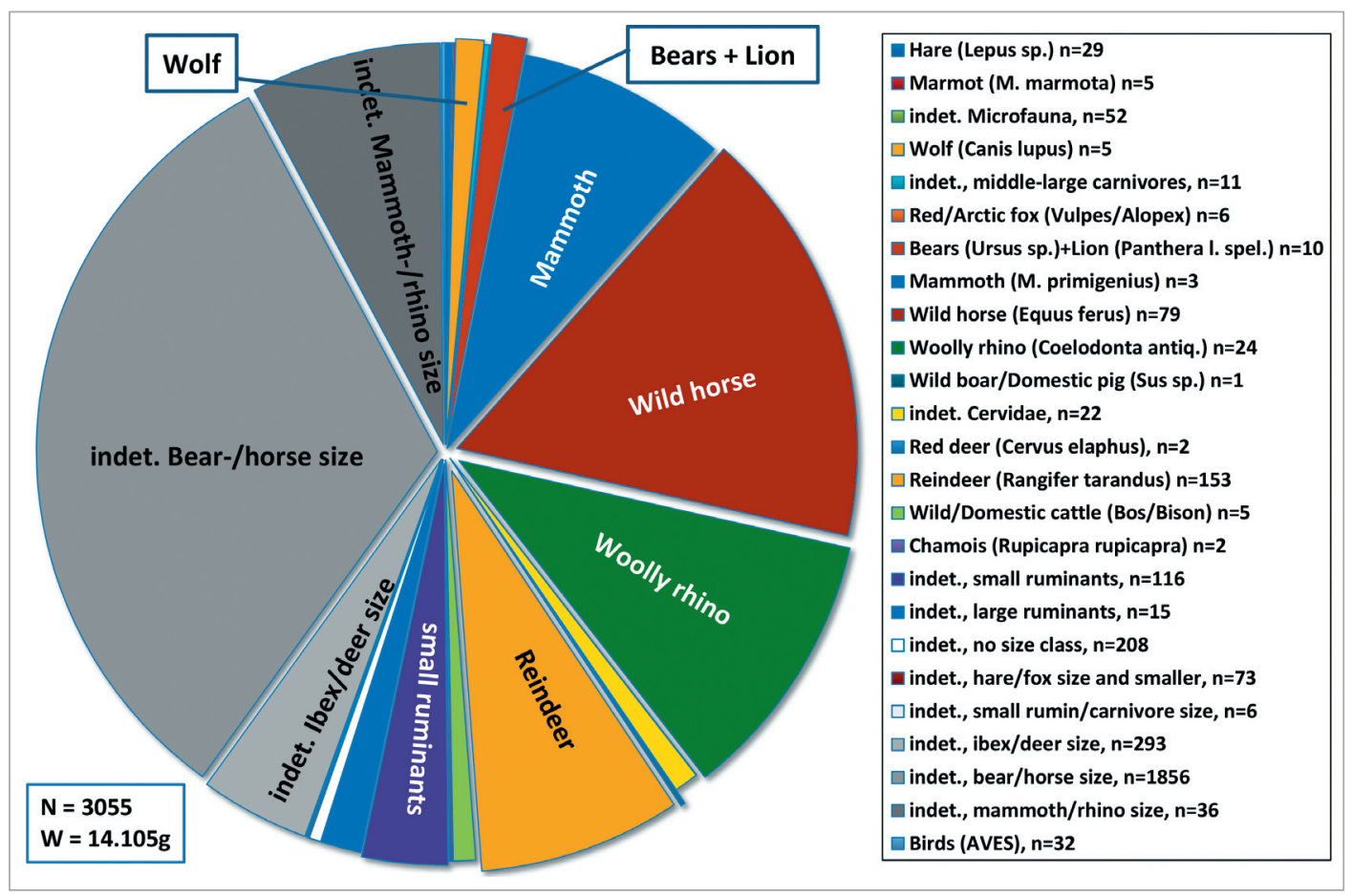

Fig. 10.

Pie chart of fauna by bone weight.
The identifiable fauna revealed characteristic species for the Pleistocene Mammoth steppe environment (Guthrie 1990), such as mammoth (Mammuthus primigenius), woolly rhino (Coelodonta antiquitatis), wild horse (Equus ferus) and reindeer (Rangifer tarandus). Based on bone weight, horse is the most prominent species, followed by woolly rhino and reindeer (Fig. 10). Megafauna, such as mammoth, are represented by one upper molar (M4/5) and some enamel fragments, while woolly rhino is represented by several postcranial elements, such as two fragmented juvenile femora belonging to individuals of different ages, a fragmented scapula and three fragmented ribs. Woolly rhino teeth are represented by just one fragment of tooth enamel.

Other large herbivores present in the corpus are wild cattle (Bos/Bison), red deer (Cervus elaphus) and chamois (Rupicapra rupicapra). Small herbivores are represented by marmot (Marmota marmota) and hare (Lepus sp.). For most of the hare remains, a species classification is impossible, with just one upper incisor in the assemblage (I1, sup.), identified as arctic hare (Lepus timidus; Koby 1960). For the other hare remains, we cannot exclude brown hare (Lepus lepus), since both species existed coevally during the last glaciation.

The bones of carnivores are not very numerous and represented by wolf (Canis lupus, $\mathrm{n}=5$ ), red and arctic fox (Vulpes vulpes and Vulpes lagopus, identified metrically by Chris Baumann), one upper incisor of a lion 
(Panthera leo spelaea) and a few bear remains, of which one is a cave bear (Ursus spelaeus) hyoid. The presence of cave bear is unexpected in a rockshelter; they are typical to cave sites, but at Heidenschmiede the remains must have been dragged in either by other carnivores or by human hunters. Remarkably, we found no evidence of hyena among the remains.

We identified evidence of butchering marks, the favored game animals being reindeer, small to middle-sized ruminants, horse and chamois, with a predominance of reindeer (Table 7). It is likely that the woolly rhino remains are also the result of human hunting, although no traces of butchering are visible.

The remains of woolly rhino are noteworthy (Fig. 11). They include two right femora of two young individuals of different ages. The femur length of the smaller individual correlates with the length of a mounted skeleton in the Zoological Collection at the University of Tübingen (Inv.nr. Mam 370). This reference skeleton has fully erupted milk teeth. The fourth deciduous molars (dP4) show slight attrition, the first molars are still below the alveolar border and, in the postcranial skeleton, all epiphyses are unfused. The individual from the collection is comparable to aging stage 5, i.e., from 1.5 to 3 years old (Hillman-Smith et al. 1986). On this basis we can estimate the age of the younger femur from Heidenschmiede to between 1.5 and 3 years old. Unfortunately, this aging is not specific enough to determine the hunting season. The femur of the other woolly rhino must have been from a slightly older individual.

Two erupted horse milk molars ( $\mathrm{dP} 2$ and $\mathrm{dP} 3)$ are present in the assemblage, providing evidence for the presence of a young foal at the site. These show slight attrition. The shape of the third deciduous molar (dP3) indicates that the dP4 has not fully erupted. These milk teeth can be estimated to an age of circa 6 months (Habermehl 1975: 31, Fig. 4), indicating that this foal was probably hunted in the summertime during the first year of its life.
Table 7.

Anthropogenic modifications.

\begin{tabular}{|c|c|c|c|c|c|c|}
\hline Taxon & impact & cut mark & $\begin{array}{l}\text { impact+ } \\
\text { cut mark }\end{array}$ & scraping & retoucher & Total \\
\hline Equus ferus & 2 & 2 & & & 1 & 5 \\
\hline Rangifer tarandus & 9 & 5 & 5 & 3 & 1 & 23 \\
\hline Rupicapra rupicapra & & 1 & & & & 1 \\
\hline indet. Cervidae & & 1 & & 2 & & 3 \\
\hline Bos/Bison & & & & & 2 & 2 \\
\hline indet. small ruminant & 1 & 1 & 1 & & 1 & 4 \\
\hline indet. small bovid & 1 & & & & & 1 \\
\hline indet. reindeer/ibex size & 1 & 5 & 1 & & & 7 \\
\hline indet. horse/bear size & 1 & 1 & & & 2 & 4 \\
\hline Aves & & & 1 & & & 1 \\
\hline Total & 15 & 16 & 8 & 5 & 7 & 51 \\
\hline
\end{tabular}


Fig. 11.

Two juvenile left femora of woolly rhino (Coelodonta antiquitatis) from Heidenschmiede.

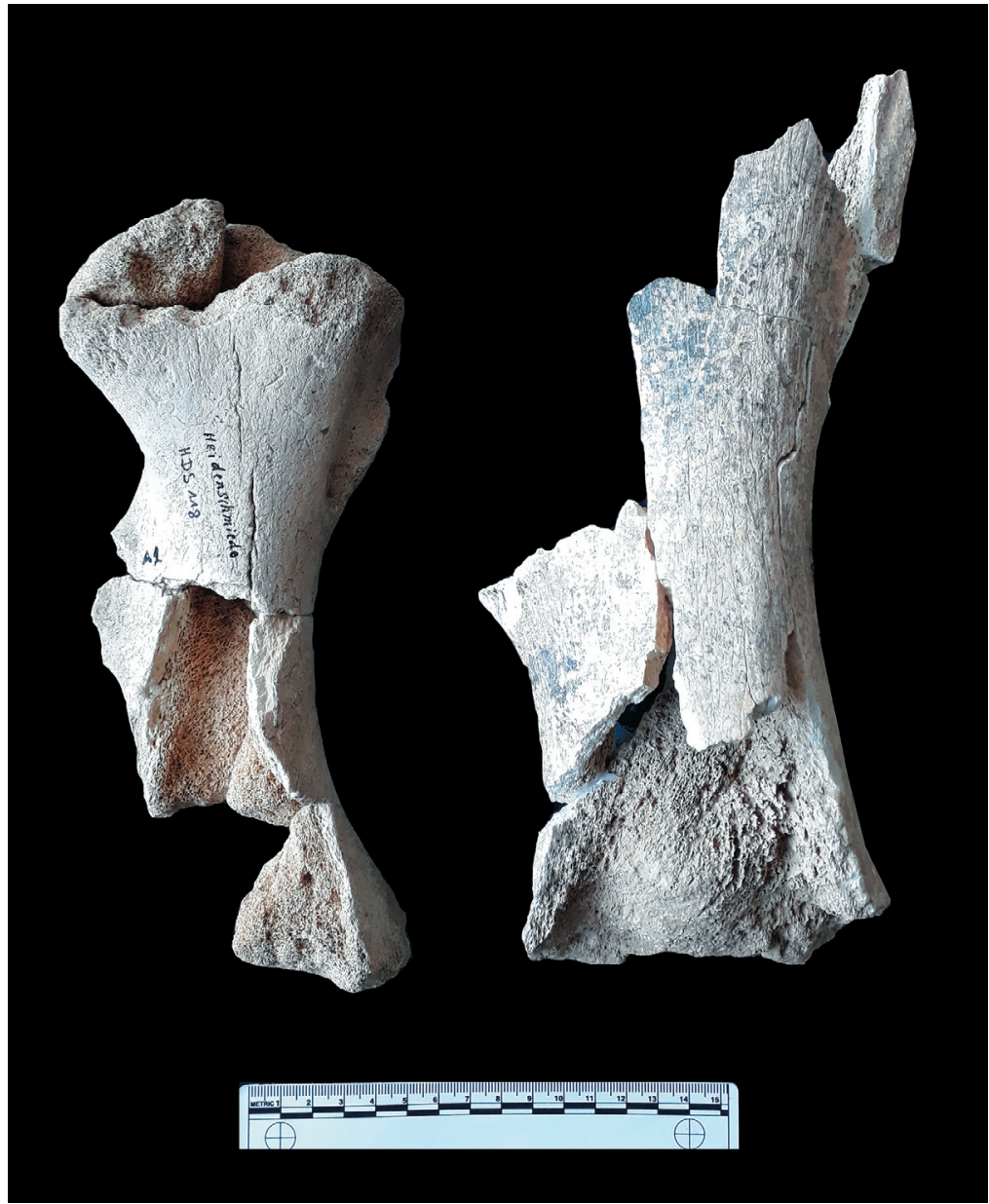

Hearths and fuel

Evidence of human occupation in the Heidenschmiede faunal assemblage is provided by the relatively high proportion of burnt bones, although Peters (1931) does not mention any hearth structures or fire places; he only mentions $0.7 \mathrm{~kg}$ of burnt bones. But almost 50\% ( $\mathrm{n}=1514)$ of the bone fragments and $23 \%$ (or $3.22 \mathrm{~kg}$ ) of the total bone weight are charred; several pieces are very large, up to $70 \mathrm{~mm}$ with a compacta thickness of up to $30 \mathrm{~mm}$ (Fig. 12). Bones of megafauna such as mammoth or rhino must have been burnt in hearths. One third of the combusted bones are brown to dark brown in color and, respectively, black or grey to bluish/grey. Only a small proportion is completely calcined, exhibiting a whitish color. The block diagram (Fig. 13) is expressed in bone weight reflecting the mass, not the number, of burnt bones. The heat in the fireplace can be estimated at between $300-400^{\circ} \mathrm{C}$ for the dark to dark brownish bones and between 


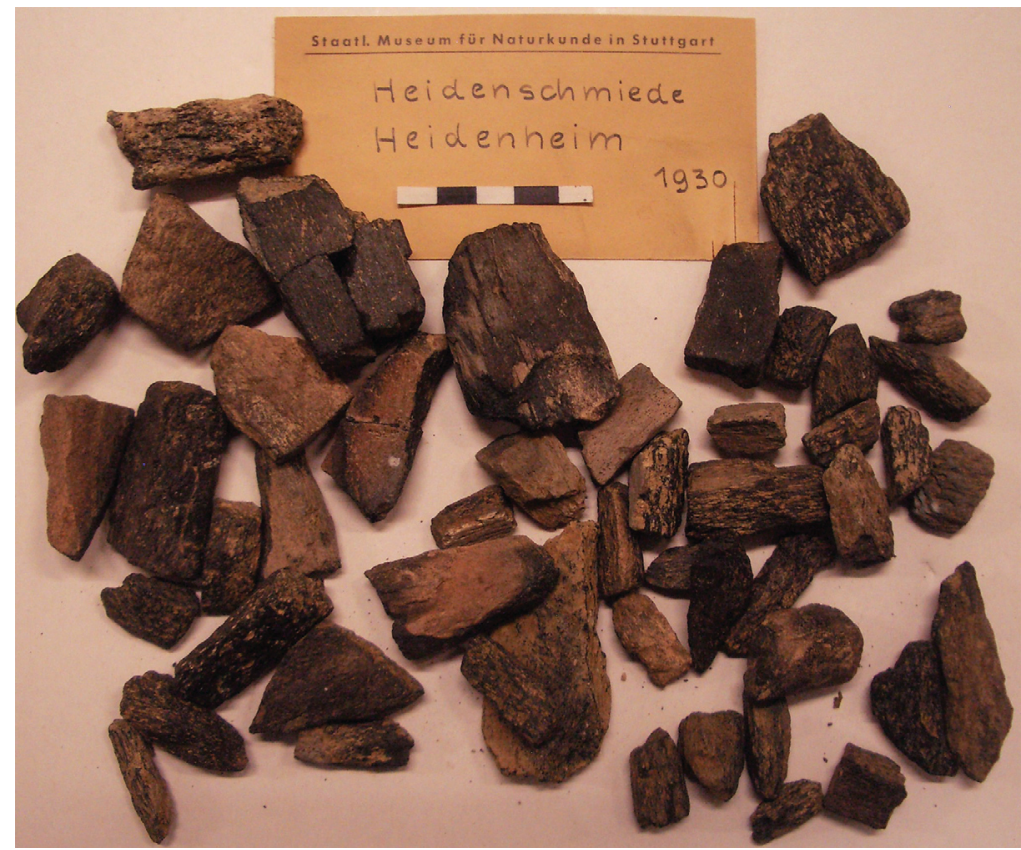

$400-550^{\circ} \mathrm{C}$ for the grey to bluish grey charred bones, and for the whitish bones somewhat higher (Wahl 1981). Therefore, most of the bones were combusted at relatively low temperatures. To maintain a fire using bones as fuel, large quantities are necessary and, as experiments have shown, the more bones included, the longer the combustion lasts (Théry-Parisot 2002).

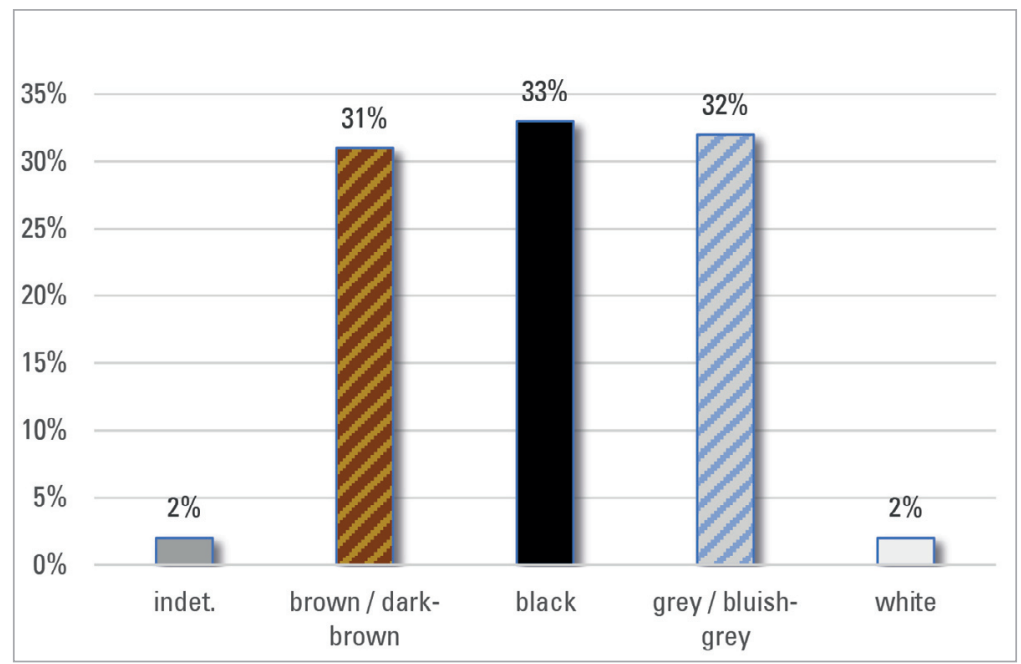

Fig. 12.

Charred bone pieces (Photo: Susanne C. Münzel).

Fig. 13.

Proportion of different combustion stages expressed in bone weight $(n=1514$, weight=3.22 kg). 
Fig. 14.

Bone retouchers:

a) HDS 321 ; b) HDS 119 ;

c) HDS 343; d) HDS 334;

e) HDS 120 (Photos: Yvonne

Berardi).

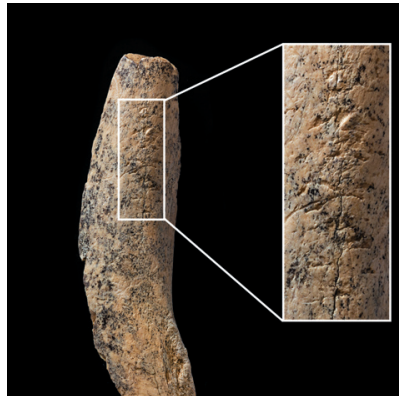

a
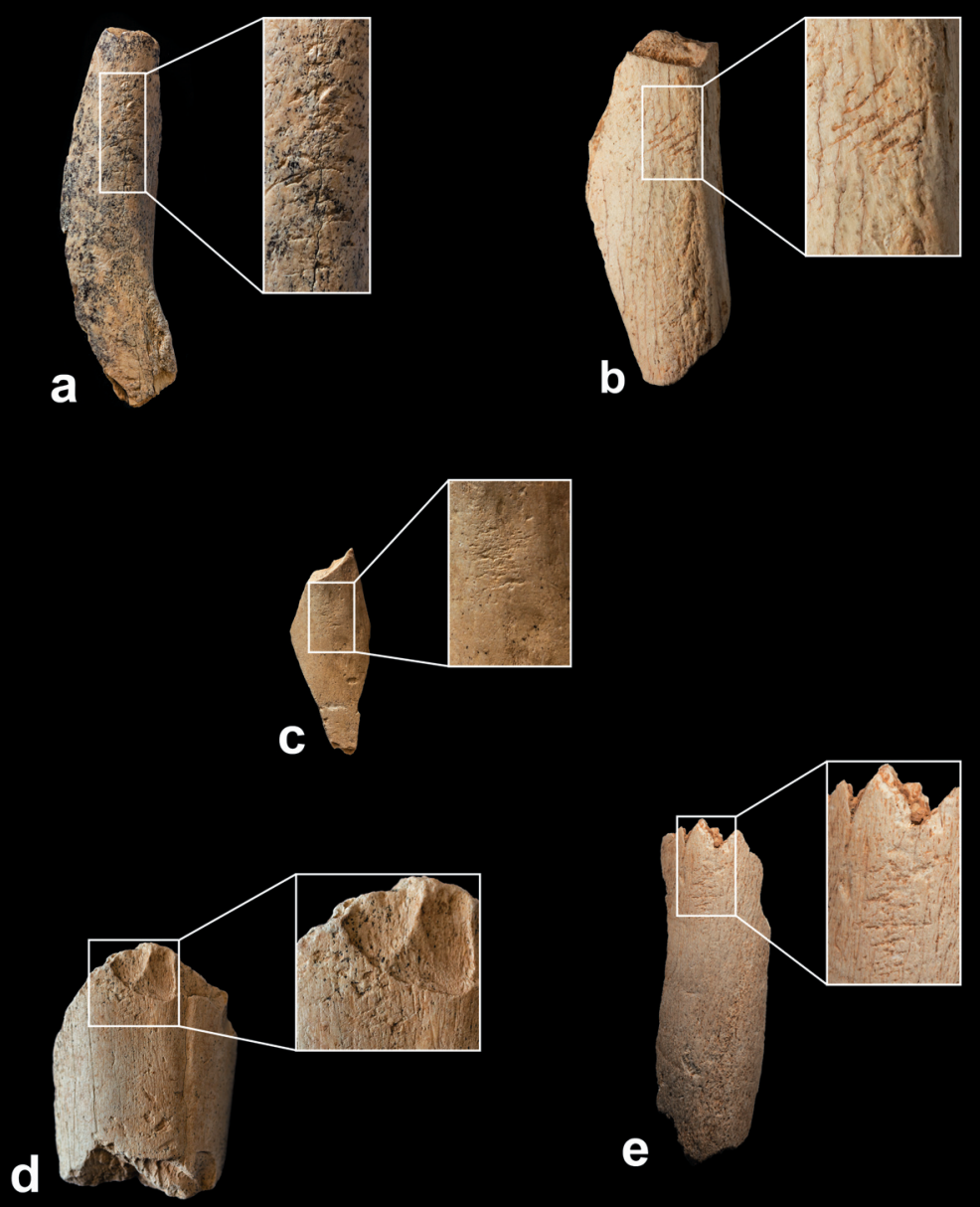

d

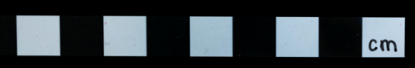

Organic tools

A very important organic tool group at the site includes seven bone retouchers (Fig. 14 and Tab. 8), of which one was dated (Table 1). Two were recognized and published by Peters (1931, plate IV, 4, 5). Six of the seven retouchers are made on long bones and one on the basal fragment of a mandible (Fig. 14e, HDS 120). Five retouchers have one use area with scars and two pieces might have two use areas (Fig. 14b+d, HDS 119, HDS 334). Four of the seven tools show scraping of the compacta (Table 8), which probably relates to the preparation of the retouchers by removel of the pe- 


\begin{tabular}{|l|l|l|l|l|}
\hline $\begin{array}{l}\text { Data base } \\
\text { number }\end{array}$ & Species/element & Traits & $\begin{array}{l}\text { Inventory number of } \\
\text { museum }\end{array}$ & Reference \\
\hline HDS 119 & $\begin{array}{l}\text { Horse, left tibia shaft } \\
\text { fragment }\end{array}$ & Eventually 2 use areas & WLM S 83.6; Nr. 167 & $\begin{array}{l}\text { Peters 1931, Plate IV, 5 } \\
\text { Fig. 12b }\end{array}$ \\
\hline HDS 120 & $\begin{array}{l}\text { Horse-size, mandibula, } \\
\text { basal corpus fragment }\end{array}$ & $\begin{array}{l}\text { Scraping of compacta } \\
\text { and 1 use area }\end{array}$ & WLM S 83.6; Nr. 168 & $\begin{array}{l}\text { Peters 1931, Plate IV, 4 } \\
\text { Fig. 12e }\end{array}$ \\
\hline HDS 197 & $\begin{array}{l}\text { Bear-/horse-size, long } \\
\text { bone shaft fragment }\end{array}$ & $\begin{array}{l}\text { Small piece of a fragmented } \\
\text { retoucher with scraping } \\
\text { and 1 use area }\end{array}$ & IN8013/FB4682.1 & Not depicted \\
\hline HDS 321 & $\begin{array}{l}\text { Reindeer, right tibia } \\
\text { shaft fragment }\end{array}$ & $\begin{array}{l}\text { Scraping of compacta } \\
\text { and 1 use area }\end{array}$ & IN8039 & Fig. 12a \\
\hline HDS 334 & $\begin{array}{l}\text { Bos/Bison, metacarpal } \\
\text { shaft fragment }\end{array}$ & $\begin{array}{l}\text { Scraping of compacta, } \\
\text { eventually 2 use areas and } \\
\text { splintering on both ends }\end{array}$ & IN8039 & Fig. 12d \\
\hline HDS 343 & $\begin{array}{l}\text { Small ruminant, femur } \\
\text { shaft fragment }\end{array}$ & Very fine scars in 1 use area & IN8039 & Fig. 12c \\
\hline HDS 438 & $\begin{array}{l}\text { Bos/Bison, metacarpal } \\
\text { shaft fragment }\end{array}$ & $\begin{array}{l}\text { Compacta broken with } \\
\text { probably 1 use area }\end{array}$ & IN8039 & Not depicted, 14C dated \\
\hline
\end{tabular}

riosteum before their use (Toniato et al. 2018). Such traces were also found on some other reindeer and cervid long bones from Heidenschmiede (Table 7). One retoucher (HDS 334) made from a Bos/Bison metacarpal shows splintering on both ends. The flakes attest to a chaîne opératoire: first the compacta of the metacarpal was scraped; it was subsequently used as a retoucher; finally it was used for another purpose, possibly as a punch, which resulted in flaking on both ends of the object. This chaine opératoire is also evident on another retoucher from the Swabian Jura, namely from Geißenklösterle Cave (Ach valley; Toniato et al. 2018: 8, Fig. 4).

\section{FAUNAL CONCLUSIONS}

The location of Heidenschmiede rockshelter above the Brenz River was a perfect viewing point from which Neanderthals could spot prey animals in the valley below. The proportion of human modifications for this small faunal assemblage is relatively high. In addition, traces of carnivore gnawing are not very numerous. Indeed, the absence of heavy gnawing on bones and of hyena coprolites tends to indicate that the bone accumulation in Heidenschmiede was primarily the result of human activities.

The faunal material provides evidence of a number of diverse activities, including hunting, butchering, maintaining of hearths, preparation
Table 8.

Bone retouchers. 
of organic tools and the use of bone retouchers to knap and maintain lithic tools. The hunting season for horse was possibly in summer. Concerning the frequency or duration of occupational events, we are not able to draw any conlusions from the finds because of the unstratified nature of the assemblage. However, the radiocarbon dates provide a Middle Paleolithic context. And we can probably exclude younger techno-complexes.

\section{CONCLUDING REMARKS}

In conclusion, we want to emphasize that the results presented here are preliminary and should be treated with caution since the chronological framework is lacking and the stratigraphic relationships are not clear. We should also keep in mind that the sedimentation processes in caves and rockshelters are complicated, even when they are excavated and analyzed using modern methods. This is a general problem in the cave sites of the Swabian Jura, where the assemblages often originate from older excavations.

\section{ACKNOWLEDGMENTS}

This research was financed by the Hanns-Voith Foundation in Heidenheim an der Brenz with special thanks to Meinrad Schad. We also wish to recognize the Bürgerstiftung of the Kreissparkasse Heidenheim, where our special thanks go to Stefan Aust and his team, and the city of Heidenheim, where we wish to thank Lord Major Bernhard Ilg. We also received invaluable support from the various museums that house the material. At the Schloss Museum in Heidenheim, we wish to thank Dr. Gereon Balle and Ulrike Stich, who made access to the archaeological material possible. We also wish to thank Dr. Florian Haack for supporting our work in the Landesmuseum Baden-Württemberg in Stuttgart. At the Natural History Museum Stuttgart we expresss our gratitude to Thomas Rathgeber for his continuing support. Our special thanks go to Yvonne Berardi for the photographs.

Additional support was provided by the Deutsche Forschungsgemeinschaft (DFG) as part of the project entitled Das Mittelpaläolithikum der Höhlen auf der Schwäbischen Alb.

Warm thanks also go to Gillian Wong, who took the radiocarbon samples and corrected an earlier version of this paper, and to Aurore Val for translating our Abstract into French. 


\section{LITERATURE}

Beurer, M. 1971. Kieselsäureanreicherungen in den oberjurassischen Sedimenten der Schwäbischen Alb. Beihefte zum Geologischen Jahrbuch 109. Hannover: Bundesanstalt für Bodenforschung.

Boëda, E. 1994. Le concept Levallois: variabilite des methodes. Paris: Monographie du Centre de Recherchees Archeologiques 9.

Bosinski, G. 1967. Die Mittelpaläolithischen Funde im westlichen Mitteleuropa. Fundamenta Reihe A, Band 4. Köln.

Burkert, W. 1999. Lithische Rohmaterialversorgung im Jungpaläolithikum des südöstlichen Baden-Württemberg. Unpublished Dissertation Tübingen.

Çep, B., W. Burkert, and H. Floss. 2011. Zur mittelpaläolithischen Rohmaterialversorgung im Bockstein (Schwäbische Alb). Mitteilungen der Gesellschaft für Urgeschichte 20: 33-46.

Conard, N. J. 2009. Female Figurine from the Basal Aurignacian of Hohle Fels Cave in Southwestern Germany. Nature 459: 248-252.

Conard, N. J., and B. Fischer. 2000. Are There Recognizable Cultural Entities in the German Middle Palaeolithic? In Towards Modern Humans: Yabrudian and Micoquian, 400-50 KYears Ago, ed. by A. Ronen and M. Weinstein-Evron, pp. 7-21. Oxford: BAR International Series 850 .

Conard, N. J., M. Bolus, E. Dutkiewicz, and S. Wolf. 2015. Eiszeitarchäologie auf der Schwäbischen Alb, pp. 235-238. Tübibgen: Kerns Verlag, Tübingen.

Freund, G. 1968. Mikrolithen aus dem Mittelpaläolithikum der Sesselfelsgrotte im unteren Altmühltal, Ldkr. Kelheim. Quartär 19: 133-154.

Guthrie, D. 1990. Frozen Fauna of the Mammoth Steppe. The Story of Blue Babe. Chicago: University of Chicago Press.

Habermehl, K.-H. 1975. Die Altersbestimmung bei Haus- und Labortieren. Berlin: Paul Parey Verlag.

Herkert, K., M. Siegeris, J.-Y. Chang, N. J. Conard, and H. Floss. 2005. Zur Ressourcennutzung später Neandertaler und früher moderner Menschen. Fallbeispiele aus dem südlichen Burgund und der Schwäbischen Alb. Mitteilungen der Gesellschaft für Urgeschichte 24: 141-172.

Higham, T., L. Basell, R. Jacobi, R. Wood, C. Bronk Ramsey, and N. J. Conard. 2012. Testing Models for the Beginnings of the Aurignacian and the Advent of Figurative Art and Music: The Radiocarbon Chronology of Geißenklösterle. Journal of Human Evolution 62: 664-676.

Hillgruber, F. 2007. Das Mittelpaläolithische Werkzeugspektrum der Fundstelle Neanderthal. Archäologisches Korrespondenzblatt 37: 335-346.

Hillman-Smith, A. K. K., N. Owen-Smith, J. L. Anderson, A. J. Hall-Martin, and J. P. Selaladi. 1986. Age estimation of the White rhinoceros (Ceratotherium simum). Journal of Zoology 210: 355-377.

Koby, F.-Ed. 1960. Contribution à la connaissance des lièvres fossiles, principalement de ceux de la dernière glaciation. Verhandlungen der Naturforschenden Gesellschaft Base/71/1: 149-173.

Müller-Beck, H. 1956. Das obere Altpaläolithikum in Süddeutschland. Ein Versuch zur ältesten Geschichte des Menschen. Dissertationsdruck, Hamburg. 
Peters, E. 1931. Die Heidenschmiede in Heidenheim a. Br. Eine Studie über das Altpaläolithikum in Württemberg. Fundberichte aus Schwaben NF 6: 1-36.

Richter, J. 1997. Sesselfelsgrotte III - der G-Schichten-Komplex der Sesselfelsgrotte. Zum Verständnis des Micoquien. Saarbrücken: Saarbrucker Druckerei und Verlag.

Richter, D., J. Waiblinger, and D. J. Rink. 2000. Thermoluminescence, Electron Spin Resonance and 14C-Dating of the Late Middle and Early Upper Palaeolithic Site of Geißenklösterle Cave in Southern Germany. Journal of Archaeological Science 27: 71-89.

Richter, J. 2002. Die 14C-Daten aus der Sesselfelsgrotte und die Zeitstellung des Micoquien/M. M. 0. Germania 80: 1-22.

Tafelmaier, Y. 2011. Revisiting the Middle Palaeolithic Site Volkringhauser Höhle (North Rhine-Westphalia, Germany). Quartär 58: 153-182.

Théry-Parisot, I. 2002. Fuel Management (Bone and Wood) During the Lower Aurignacian in the Pataud Rock Shelter (Lower Palaeolithic, Les Eyzies de Tayac, Dordogne, France). Contribution of Experimentation. Journal of Archaeological Science 29: 1415-1421.

Toniato, G., S. C. Münzel, B. M. Starkovich, and N. J. Conard. 2018. Middle and Upper Palaeolithic Retouchers from the Swabian Jura: Raw Materials, Curation and Use. In The Origins of Bone Tool Technologies, ed. by I. Davidson, pp. 251-267. From the conference "Retouching the Palaeolithic: Becoming Human and the Origins of Bone Tool Technology," Schloss Herrenhausen in Hannover, Germany, 21.- 23. October 2015, ed. by Jarod M. Hutson et al. Heidelberg: Propylaeum (RGZM - Tagungen, Band 35).

Wahl, J. 1981. Beobachtungen zur Verbrennung menschlicher Leichname. Archäologisches Korrespondenzblatt 11: 271-279.

Weißmüller, W. 1995. Sesselfelsgrotte II - die Silexartefakte der unteren Schichten der Sesselfelsgrotte. Ein Beitrag zum Problem des Moustérien. Saarbrücken: Saarbrucker Druckerei und Verlag. 